\title{
COMMENTARY
}



\section{Anthropocene: Transdisciplinary Shorthand for Human Disruption of the Earth System}

\section{Emlyn Koster}

\section{Adjunct Professor}

Department of Marine, Earth and Atmospheric Sciences

North Carolina State University, Raleigh

North Carolina 27695, USA

E-mail:koster.emlyn@gmail.com

\section{SUMMARY}

Increasingly, deliberations to potentially add the Anthropocene to the Geological Time Scale in recognition of humanity's environmental impacts and stratigraphic record are attracting interest from non-geological disciplines and the news media. The 35 member Anthropocene Working Group, a constituent body of the International Commission on Stratigraphy, recently concluded that the worldwide fallout of radionuclides from atomic bomb testing in the mid-20 $0^{\text {th }}$ century best defines the base of the Anthropocene. With a search for the optimal 'golden spike' locality in progress as a key step toward any ratification by the International Union of Geological Sciences, there are widely held views outside of geological circles that the Anthropocene is already designated as an epoch. Regard- less of its eventual formal or informal standing, this article opines that the term Anthropocene has become valuable shorthand for recognizing humanity as the dominant species which, in a geological nanosecond, has extensively detached itself from the Earth System, endangering the future of both. Accordingly, this article urges the entire geological profession to engage with the work of the Anthropocene Working Group and, as the originator of the term, to coalesce its activities with those of other disciplines concerned with environmental health and linked human health challenges.

\section{RÉSUMÉ}

De plus en plus, les délibérations visant à éventuellement ajouter l'Anthropocène à l'échelle du temps géologique en reconnaissance des impacts environnementaux de l'humanité et des données stratigraphiques suscitent l'intérêt des disciplines non géologiques et des médias. Les 35 membres du Groupe de travail sur l'Anthropocène, un organe constitutif de la Commission internationale de stratigraphie, ont récemment conclu que les retombées mondiales des radionucléides résultant des essais de bombes atomiques au milieu du XXe siècle définissent le mieux la base de l'Anthropocène. Avec la recherche de la localité de référence optimale du «clou d'or» en cours comme étape clé vers toute ratification par l'Union internationale des sciences géologiques, il existe des opinions largement partagées en dehors des cercles géologiques selon lesquelles l'Anthropocène est déjà désigné comme une époque. Indépendamment de sa position finale formelle ou informelle, cet article estime que le terme Anthropocène est devenu un raccourci précieux pour reconnaitre l'humanité comme l'espèce dominante qui, dans une nanoseconde géologique, s'est largement dissocié du système terrestre, mettant en danger l'avenir des deux. Par conséquent, cet article exhorte l'ensemble de la profession géologique à s'engager dans les travaux du Groupe de travail sur l'Anthropocène et, en tant que créateur du terme, à fusionner ses activités avec celles d'autres disciplines concernées par la santé environnementale et les défis liés à la santé humaine.

\section{LOOKING BACK}

The term Anthropocene was launched 20 years ago with anxious viewpoints that "the effects of humans on the global environment bave escalated" and that "a daunting task lies abead for scientists and engineers to guide society towards environmentally sustainable management" (Crutzen and Stoermer 2000; Crutzen 2002). Between 
2006 and 2008, the Geological Society of London and Geological Society of America reported their initial considerations, as recalled by Zalasiewicz et al. (2017), and the term began to attract interest from non-geological disciplines (Robin and Steffen 2007). In 2009 the International Commission on Stratigraphy, a constituent body of the International Union of Geological Sciences, commissioned an Anthropocene Working Group (AWG) to explore this possible new unit of time. Its chair wondered what it will turn out to be: "An age or epoch? Will it develop into a period or even an era? Or (beaven belp us if that happens) an eon?" (Zalasiewicz 2008).

In 2010 the chair and three members of the AWG declared: "The Anthropocene represents a new phase in both bumankind and of the Earth, when natural forces and human forces became intertwined, so that the fate of one determines the fate of the other" (Zalasiewicz et al. 2010). The term then entered the public realm with magazine features and editorial opinions (e.g. The Economist 2011; The New York Times 2011). In 2013-14, Elsevier and Sage launched The Anthropocene and The Anthropocene Review as journals and in 2016 Future Earth launched Anthropocene, Innovation in the Human Age as a public subscription magazine. The New York Times Magazine (Rich 2018) devoted an entire issue to revisiting 1979-1989 when the causes and dangers of climate change became broadly understood. Oxford University Press added the Anthropocene to its handbook collection of summarized topics (Ellis 2018), and Elsevier published the Encyclopedia of the Anthropocene (Dellasala and Goldstein 2018).

At its spring 2019 meeting, the 34-member AWG reached binding $97 \%$ and $88 \%$ votes to regard the Anthropocene as a chronostratigraphic unit with the mid- $20^{\text {th }}$ century as its base, noting that the worldwide fallout of radionuclides from atomic bomb testing is "the sharpest and most globally synchronous" signal "that may form a primary marker" (Anthropocene Working Group 2019). As became clear at the dawn of the $21^{\text {st }}$ century, the mid-20 th century was also when global population, industrial activity, and humanity's adverse impacts on itself and the Earth System began to increase markedly (Steffen et al. 2005). A major step in the history of the Anthropocene concept occurred on 16 January 2015:

\footnotetext{
"Today, we (the International Geosphere-Biosphere Programme and Stockholm Resilience Centre) publish a dashboard of 24 indicators which depict the dramatic acceleration in buman enterprise and the impacts on the Earth system over the last two centuries ... What is apparent is the synchronous acceleration of trends from the 1950s to the present day - over a single human lifetime - with little sign of abatement... These trends are known as the Great Acceleration" (Broadgate 2015; International Geosphere-Biosphere Programme 2015).
}

When the Anthropocene Working Group anticipated that the Anthropocene would be defined by a standard Global Boundary Stratotype Section and Point (i.e. "a golden spike"), it also noted its use in "a non-chronostratigraphic context as an informal term to denote a broader interpretation of anthropogenic impact on the planet that is markedly diachronous." Relevant investigations include the role of early humans in the extinction of Pleistocene megafauna (Malhi et al. 2016; Plotnick and Koy 2020) and the surging environmental control of the biosphere by humanity, particularly since the $16^{\text {th }}$ century (Lewis and Maslin 2018). Other examples are a review of evidence for human modification of rivers beginning around 15,000 years ago (Gibling 2018) and a collaboration of archaeologists who detected land-use transformations by hunter-gatherers, farmers and pastoralists earlier than reconstructions commonly used by geologists (Stephens et al. 2019). The archaeosphere is a proposed label for the surface part of the geosphere with "an abrupt surface at the base of [these] deposits variously called 'artificial ground', 'anthropogenic ground' or 'archaeological stratigraphy" (Edgeworth et al. 2015).

\section{WIDENING CONTEXT}

Broadgate (2015) noted: "When Paul Crutzen first proposed the idea of the Anthropocene, he suggested it probably began as the Industrial Revolution kicked off around 1800". Steffen et al. (2015) clarified: "Of all the candidates for a start date for the Anthropocene, the beginning of the Great Acceleration is by far the most convincing from an Earth System science perspective ... It is only beyond the mid-20 $0^{\text {th }}$ centu$r y$ that there is clear evidence for fundamental shifts in the state and functioning of the Earth System that are beyond the range of variability of the Holocene, and driven by human activities and not by natural variability." Reflecting the human dimension of the Anthropocene discussion, Steffen et al. (2018) stated: "While recognizing that different societies around the world have contributed differently and unequally to pressures on the Earth System and will have various capabilities to alter future trajectories, the sum total of buman impacts on the system need to be taken into account for analyzing future trajectories of the Earth System."

In 2014, the University of Wisconsin-Madison hosted an international workshop of activists, artists, humanists, and scientists to consider what kinds of museum objects would illuminate relationships between humans and non-humans (Robin 2018a). Nixon (2017) wondered: "How can we most effectively curate and narrate the Anthropocene, an idea that can seem, by turns, dauntingly compendious and elusively abstract?" The term has also become a frame of reference in the environmental humanities (Castree 2014), philosophical discourse about the direction of humanity (Scranton 2015), political perspectives on the changing relationship between humanity and nature (Purdy 2015), the evolution of purpose in museums (Möllers et al. 2015; Koster 2019), and the latest threshold in the development of the Universe (Christian 2019).

As the following examples demonstrate, the Anthropocene has captured the attention of disciplines beyond the Earth Sciences and climatology. A former New York Times science reporter assessed the term as "common shorthand for this turbulent, momentous, unpredictable, hopeless, bopeful time — duration and scope unknown" (Revkin 2016). A researcher in geography and environmental studies viewed it as

\footnotetext{
"a key theme in contemporary speculations about the meaning of the present and the possibilities for the future ... how the Anthropocene is interpreted, and who gets to invoke which framing of the
} 
new buman age ... matters greatly for both the planet and for particularparts of bumanity ... [this] requires careful evaluation for how geology has recently become so important in global politics, and how scholars from various disciplines might now usefully contribute to the discussion" (Dalby 2016).

"A heady mix of science, philosophy, and politics linked to our deepest fears and utopian visions" is how Yale University Press introduced an outlook on the Anthropocene by two Earth scientists (Lewis and Maslin 2018). Revisiting the visionary outlook of the explorer Alexander von Humboldt (1769-1859), Jackson (2019) surmised: "The Anthropocene discussion focuses attention on a fundamentally Humboldtian observation: bumanity and nature are deeply intertwined ... nature would persist in the absence of bumanity, but bumanity cannot exist without nature." A humanities scholar (Schaberg 2019) offered this assessment: "Debated, denied, unheard of, encompassing, the Anthropocene is a vexed topic and requires interdisciplinary imagination." At the College of the Atlantic in Bar Harbor, the first US college to go carbon-neutral and where all students study human ecology, a geologist and anthropologist coteach an intermediate-level course titled The Anthropocene.

\section{TAKING STOCK}

Reflecting on a prediction by astronomer Fred Hoyle in 1948 that the first photographs of the Earth from space would alter the course of history (Bartusiak 2018), it might reasonably be concluded that all that is encompassed by the Anthropocene term amounts to the most consequential alteration. Twentyone years after Hoyle's foresight, NASA's Apollo 11 mission to the Moon gave an estimated television audience of 600 million - $20 \%$ of the world population - new perspectives about the entire Earth and human ingenuity (Hsu 2019). At the first Earth Day in 1970, an estimated 20 million participants demonstrated the power of civic action to spur environmental stewardship. In 1992, 2017 and 2019, large and diverse groups of concerned scientists, including many Nobel laureates, issued increasingly publicized warnings about the escalating rates of climate change and related environmental impacts (e.g. Ripple et al. 2019).

Technological progress that has enabled exploration of interplanetary space has not been matched by environmental stewardship on Earth. A pessimistic commentary by Roberts (2020) refers to "a civilization estranged from Earth". This planet's health in an Anthropocene context was the focus of a joint commission by the medical journal Lancet and the Rockefeller Foundation "based on the understanding that human health and buman civilization depend on flourishing natural systems and the wise use of those natural systems" (Whitmee et al. 2015). The coronavirus pandemic in 2020 has hastened the need for a seamless approach to the virosphere which refers to the world of viral diversity within the biosphere (Zimmer 2020).

With geology traditionally focused on the distant past, the focus on the Anthropocene to date has largely been on its chronological and stratigraphic dimensions. This emphasis likely explains why geologists seldom add their perspectives on teachable moments surrounding news stories about the modern natural world, such as the extinction of a species, peak oil, seismic events attributed to hydraulic fracturing, transoceanic tsunamis, rising frequencies of climate records, coastal subsidence and inundation, and the ubiquity of plastic waste. In particular, potential tipping points during periods of accelerated warming are strong opportunities for raising public awareness. Recent examples are updated investigations of sea-level rise (Kulp and Strauss 2019), the Florida-sized Thwaites Glacier in eastern Antarctica (Aguilera 2019), the Greenland ice sheet (Davis 2020), and, as an illustration of the field of glacial archaeology, the significance of artefacts along a medieval Viking trail in Norway exposed by receding ice (Pilø et al. 2020). Clearly, authoritative statements on climate change by associations of geoscientists (e.g. The Geological Society 2013; Geological Society of America 2015) are desirable steps, but projecting these into the public realm requires the geosciences to develop better marketing expertise to spread these important messages. Anthropology, "the discipline most clearly devoted to the buman condition over time and space", set a high bar for its framing of climate change in a 137-page task force report (Fiske et al. 2014).

A quarter-century ago, an academician jointly appointed in geology and philosophy anticipated that future geoscientific investigations would require new types of reasoning (Frodeman 1995). In 2003 in Banff, the International GeosphereBiosphere Programme considered how the Earth System and human societies could be viewed together. The results included a new project named Integrated History and Future of People on Earth (Costanza et al. 2012) which, five years ago, was consolidated under the Future Earth framework.

All things considered, a pragmatic statement on the importance of the Anthropocene would be that it recognizes humanity as the dominant species which, in a geological nanosecond, has extensively detached itself from the Earth System, endangering the future of both. The daunting whole picture of impacts involves awareness of the natural versus altered states of all 'shells' comprising the Earth System (Table 1). Underscoring the case made by Koster (2011) for an unprecedented topical relevance of the geosciences are The Anthropocene Project (Burtynsky et al. 2018) which is a multimedia experience about anthropogenic impacts on the Earth's surface, interest by mainstream news in how the Anthropocene has evolved as a scientific inquiry (Davison 2019), and a visual chronicle of the Anthropocene (Steinmetz and Revkin 2020).

\section{LOOKING FORWARD}

As the profession specialized in the scientific study of the Earth and the originator of the Anthropocene concept, geoscientists can become a leading force for public awareness in the words of Crutzen (2002), "to guide society" - in these increasingly perilous times by rallying around the AWG's consensus. This task is urgent because the prevalent news about changing climates, rising sea-level and extreme weather is only one part of a more complex situation which the Anthropocene concept encompasses. As an example, worldwide loss of biodiversity has prompted consideration of a target of keeping species extinctions below twenty per year "to galvanize both political will and public support" (Rounsevell et al. 2020). 
Table 1. Summary of anthropogenic impacts on each 'shell' of the Earth System.

\section{Atmosphere}

o Includes the troposphere, the lowermost layer up to the elevation where jet planes fly and in which all weather systems and habitats for air-breathing life and photosynthesis exist.

o Anthropogenic impacts include reduced air quality due to pollution, warming due to burning of fossil fuels, ozone layer damage due to aerosols, extreme weather causing floods, wildfires and droughts, and altered averages of season length, temperature and precipitation patterns.

\section{Hydrosphere}

o All oceans and seas that contain $96.5 \%$ of the world's water and cover $71 \%$ of its surface, and all freshwater in lakes, rivers, and groundwater from which all drinking water (aside from desalination products) is derived.

o Anthropogenic impacts include widespread pollution, ocean warming causing hurricane intensification and reduction of Arctic and Antarctic sea ice, ecosystem shifts, river flow disruptions, coral reef bleaching, ubiquitous plastic debris, and sealevel rise mainly due to melting ice sheets, icecaps and glaciers, locally exacerbated by coastal subsidence.

\section{Cryosphere}

o All frozen areas of the Earth's surface, including ice-sheets, icecaps, glaciers, and tundra.

o The Antarctica ice sheet and Greenland icecap contain the equivalents of approx. $60 \mathrm{~m}$ and $6 \mathrm{~m}$ of worldwide sea-level rise, respectively.

o Anthropogenic impacts include melting of permafrost with methane emissions and accelerated melting of glacial ice which is often a vital source to river flow and water for piedmont communities and agriculture.

\section{Biosphere}

o All life-supporting habitats on, just below and above land and ocean surfaces.

o Includes the virosphere, the world of virus diversity such as Covid-19.

o Extensively inhabited and affected by humanity (the Earth's dominant species) and these impacts have grown with the Great Acceleration since the mid-20 th century.

o Anthropogenic impacts include pollution, disruptions of ecosystems, overfishing, and sharply reduced biodiversity in all major faunal and floral groups, including extinctions.

\section{Lithosphere}

o Crustal layer, 5 to $65 \mathrm{~km}$ thick, in which plate tectonics operates, volcanic activity and earthquakes originate, and from where fossil fuels and mineral resources are extracted.

o Includes the pedosphere: the thin outermost layer of agriculture-enabling soil where rock and sediment are altered by linked physical, chemical, and organic processes.

o Includes the archaeosphere: proposed term for the altered, highly varied, surface layer of the lithosphere containing evidence of human activities and impacts.

o Anthropogenic impacts include disposal of radioactive waste, groundwater pollution, aquifer alteration, impacts from hydraulic fracturing of rocks for recovery of hydrocarbons, and the predicted imminence of 'peak soil' and 'peak oil'.

The International Union of Geological Sciences - the arbiter on the final status of the Anthropocene - is a member of the International Science Council which resulted from fusion in 2017 of the International Council for Science and International Social Science Council, founded in 1931 and 1952, respectively. This is a clearly helpful context for the geosciences because the Anthropocene has such wide significance. As Robin (2018b) proclaimed: "The task of reconceptualizing planetary change for the buman imagination calls for a wide range of disciplinary wisdom". Accordingly, the geosciences need to establish a common horizon not only with other scientific disciplines but also with the social sciences which explore how people understand the world and their place in it. As an example, Semeniuk (2020) drew attention to likely shifts in humanity's comfort zone due to climate change resulting from unchecked carbon emissions. As disquieting as such projections are, shifts in cli- mate are just one facet of the global changes that are embodied in the concept of the Anthropocene. If its 'golden spike' does turn out to be the fallout from the first atomic bomb tests, this new geological time will become a paradoxical reminder of the first resolution of the United Nations General Assembly in 1946 which called for peaceful uses of atomic energy and elimination of weapons of mass destruction.

A musing about the passage of time (Brannen 2018) provided an apt conclusion for this article:

"The world is old beyond comprehension, and our story on it is short. But if we are to endure as a civilization, or even as a species, for anything more than might amount to a thin layer of odd rock in some wind-swept canyon of the far future, some bumility is in order about our, thus far, infinitesimal part in the history of the planet." 


\section{ACKNOWLEDGEMENTS}

The author thanks Philip Gibbard, emeritus professor of Quaternary Palaeoenvironments at the University of Cambridge and a member of the Anthropocene Working Group, for ongoing dialogue around the development of the Anthropocene concept. Martin Gibling, emeritus professor of Earth and Environmental Sciences at Dalhousie University, and Lucy Laffitte, vice president of the International Big History Association, also valuably commented on drafts of this article. Appreciation also goes to Andy Kerr and Cindy Murphy, scientific editor and managing editor, respectively, for Geoscience Canada.

\section{REFERENCES}

Aguilera, J., 2019, A glacier the size of Florida is becoming unstable. It has dire implications for global sea levels: Time, July 11.

Anthropocene Working Group, 2019, Results of binding vote by Anthropocene Working Group, Released May 21, 2019: Subcommission on Quaternary Stratigraphy. Available from: quaternary.stratigraphy.org/working-groups/ Anthropocene/.

Bartusiak, M., 2018, How photos of Earth from space changed humans' view of their life on the planet: The Washington Post, February 9.

Brannen, P., 2018, Rambling through time: The New York Times, January 27.

Broadgate, W., 2015, The Great Acceleration: Future Earth. Available from: https://futureearth.org/2015/01/16/the-great-acceleration/.

Burtynsky, E., Baichal, J., and de Pencier, N., 2018, The Anthropocene Project. Available from: https://www.edwardburtynsky.com/projects/the-anthropocene-project.

Castree, N., 2014, The Anthropocene and the environmental humanities: extending the conversation: Environmental Humanities, v. 5, p. 233-260, https://doi.org/ 10.1215/22011919-3615496

Christian, D., 2019, Origin story: Little, Brown and Company, 357 p.

Costanza, R., van der Leeuw, S., Hibbard, K., and 16 others, 2012, Developing an integrated history and future of people on Earth (IHOPE): Current Opinion in Environmental Sustainability, v. 4, p. 106-114, https://doi.org/10.1016/ j.cosust.2012.01.010.

Crutzen, P.J., 2002, Geology of mankind: Nature, v. 415, p. 23, https://doi.org/ 10.1038/415023a.

Crutzen, P.J., and Stoermer, E.F., 2000, The "Anthropocene": International Geosphere-Biosphere Programme, Global Change Newsletter no. 41, p. 17-18.

Dalby, S., 2016, Framing the Anthropocene: The good, the bad and the ugly: The Anthropocene Review, v. 3, p. 33-51, https://doi.org/10.1177/ 2053019615618681.

Davis, N., 2020, Scientists confirm dramatic melting of Greenland ice sheet: The Guardian, April 15.

Davison, N., 2019, Best audio long reads of 2019: the Anthropocene epoch (podcast): The Guardian. Available from: https://www.theguardian.com/news/ audio/2019/dec/30/best-audio-long-reads-of-2019-the-anthropocene-epoch.

Dellasala, D.A., and Goldstein, M.I., editors, 2018, Encyclopedia of the Anthropocene: Elsevier, $2280 \mathrm{p}$

Edgeworth, M., deB Richter, D., Waters, C., Haff, P., Neal, C., and Price, S.J., 2015, Diachronous beginnings of the Anthropocene: the lower bounding surface of anthropogenic deposits: The Anthropocene Review, v. 2, p. 33-58, https://doi.org/10.1177/2053019614565394.

Ellis, E.C., 2018, Anthropocene: a very short introduction: Oxford University Press, 183 p., https://doi.org/10.1093/actrade/9780198792987.001.0001.

Fiske, S.J., Crate, S.A., Crumley, C.L., Galvin, K., Lazrus, H., Lucero, L. OliverSmith, A., Orlove, B., Strauss, S., and Wilk, R., 2014, Changing the atmosphere. Anthropology and climate change: Final report of the American Anthropological Association, Global Climate Change Task Force, 137 p. Available from: http://s3.amazonaws.com/rdcms-aaa/files/production/public/FileDownloads/pdfs/cmtes/commissions/upload/GCCTF-Changing-the-Atmosphere.pdf.

Frodeman, R., 1995, Geological reasoning: geology as an interpretative and historical science: Geological Society of America Bulletin, v. 107, p. 960-968. https://doi.org/10.1130/0016-7606(1995)107<0960:GRGAAI>2.3.CO;2.

Geological Society of America, 2015, Position statement on climate change: adopted in October 2006 (revised 2010, 2015, 2020): Geological Association of America. Available from: https://www.geosociety.org/documents/gsa/positions/pos10_climate.pdf.

Gibling, M.R., 2018, River systems and the Anthropocene: a Late Pleistocene and Holocene timeline for human influence: Quaternary, v. 1, no. 21, https://doi.org/10.3390/quat1030021.

Hsu, T., 2019, The Apollo 11 mission was also a global media sensation: The New York Times, July 15
International Geosphere-Biosphere Programme, 2015, Planetary dashboard shows "Great Acceleration" in human activity since 1950: IGBP Press Release. Available from: http://www.igbp.net/news/pressreleases/pressreleases/planetarydashboardshowsgreataccelerationinhumanactivitysince1950.5.950c2fa1495db7 081eb42.html.

Jackson, S.T., 2019, Humboldt for the Anthropocene: Science, v. 365, p. 1074-1076, https://doi.org/10.1126/science.aax7212

Koster, E., 2011, The Anthropocene: an unprecedented opportunity to promote the unique relevance of geology to societal and environmental needs: Geoscientist, v. 21 , no. 9, p. 18-21.

Koster, E., 2019, The Anthropocene as our conscience, in Designing for empathy: perspectives on the museum experience, E. Gokcigdem, Rowman and Littlefield, p. 345-362.

Kulp, S.A., and Strauss, B.H., 2019, New elevation data triple estimates of global vulnerability to sea-level rise and coastal flooding: Nature Communications, v. 10 no. 4844, https://doi.org/10.1038/s41467-019-12808-z.

Lewis, S., and Maslin, M., 2018, The human planet: how we created the Anthropocene: Yale University Press, $465 \mathrm{p}$

Malhi, Y., Doughty, C.E., Galetti, M., Smith, F.A., Svenning, J.-C., and Terborgh, J.W., 2016, Megafauna and ecosystem function from the Pleistocene to the Anthropocene: Proceedings, National Academy of Sciences, v. 113, p. 838-846, https://doi.org/10.1073/pnas.1502540113.

Möllers, N., Schwägerl, C. and Trischler, H., 2015, Welcome to the Anthropocene: the Earth in our hands: Deutsches Museum and Rachel Carson Center for Environment and Society, 203 p.

Nixon, R., 2017, The Anthropocene and environmental justice, in Newell, J., Robin, L., and Wehner, K., eds., Curating the future: museums, communities and climate change: Routledge, p. 23-31.

Pilø, L., Finstad, E., and Barrett, J.H., 2020, Crossing the ice: an Iron Age to medieval mountain pass at Lendbreen, Norway: Antiquity, v. 94, p. 437-454, https://doi.org/10.15184/aqy.2020.2.

Plotnick, R.E., and Koy, K.A., 2020, The Anthropocene fossil record of terrestrial mammals: Anthropocene, v. 29, 100233, https://doi.org/10.1016/ j.ancene.2019.100233

Purdy, J., 2015, After nature: A politics for the Anthropocene: Harvard University Press, 336 p., https://doi.org/10.4159/9780674915671.

Revkin, A.C., 2016, An Anthropocene journey: Future Earth, Anthropocene - Innovation in the Human Age Magazine 1: p. 62-75.

Rich, N., 2018, Thirty years ago, we could have saved the planet: The New York Times Magazine, $70 \mathrm{p}$.

Ripple, W.J., Wolf, C., Newcome, T.M., Barnard, P., and Moomay, W.R., 2019, World scientists' warning of a climate emergency: BioScience, v. 70, p. 8-12, https:// doi.org/10.1093/biosci/biz088.

Roberts, H., 2020, This Earth Day, we should repent: The New York Times, April 20 .

Robin, L., 2018a, Anthropocene cabinets of curiosity: objects of strange change, in Mitman, G., Armiero, M. and Emmet, R., eds., Future remains: a cabinet of curiosities for the Anthropocene: University of Chicago Press, p. 205-218.

Robin, L., 2018b, Environmental humanities and climate change: understanding humans geologically and other life forms ethically: WIREs Climate Change, v. 9, no. 1, https://onlinelibrary.wiley.com/doi/abs/10.1002/wcc.499.

Robin, L., and Steffen, W., 2007, History for the Anthropocene: History Compass, v. 5, p. 1694-1719, https://doi.org/10.1111/j.1478-0542.2007.00459.x.

Rounsevell, M.D.A., Harfoot, M., Harrison, P.A., Newbold, T., Gregory, R.D., and Mace, G.M., 2020, A biodiversity target based on species extinctions: Science, v. 368, p. 1193-1195, https://doi.org/10.1126/science.aba6592.

Schaberg, C., 2019, Searching for the Anthropocene, a journey into the environmental humanities: Bloomsbury Academic, 224 p., https://doi.org/10.5040/ 9781501351860

Scranton, R., 2015, Learning to die in the Anthropocene: reflections on the end of civilization: City Lights Publishers, 142 p.

Semeniuk, I., 2020, Climate change could leave billions in areas unfit for human life, study shows: The Globe and Mail, May 5.

Steffen, W., Sanderson, R.A., Tyson, P.D., Jäger, J., Matson, P.A., Moore III, B., Oldfield, F., Richardson, K., Schellnhuber, H.J., Turner, B.L., and Wasson, R.J., 2005, Global change and the Earth System: Global Chante - The IGBP Series, Springer-Verlag Berlin Heidelberg, 336 p., https://doi.org/10.1007/b137870.

Steffen, W., Broadgate, W., Deutsch, L., Gaffney, O., and Ludwig, C., 2015, The trajectory of the Anthropocene: The Great Acceleration: The Anthropocene Review, v. 2, p. 81-98, https://doi.org/10.1177/2053019614564785.

Steffen, W., Rockström, J., Richardson, K., and 13 others, 2018, Trajectories of the Earth System in the Anthropocene: Proceedings, National Academy of Sci- 
ences, v. 115, p. 8252-8259, https://doi.org/10.1073/pnas.1810141115.

Steinmetz, G., and Revkin, A., 2020, The human planet: Earth at the dawn of the Anthropocene: Abrams, New York, 256 p.

Stephens, L., Fuller, D., Boivin, N., and 117 others, 2019, Archaeological assessment reveals Earth's early transformation through land use: Science, v. 365, p. 897-902, https://doi.org/10.1126/science.aax1192.

The Economist, 2011, The Anthropocene: a man-made world: May 26.

The Geological Society, 2013, An addendum to the statement on climate change: evidence from the geological record: The Geological Society Members of the Working Group, original statement November 2010. Available from: https://www.geolsoc.org.uk/climaterecord.

The New York Times, 2011, The Anthropocene: February 27.

Whitmee, S., Haines, A., Beyrer, C., and 19 others, 2015, Safeguarding human health in the Anthropocene epoch: report of The Rockefeller Foundation-Lancet Commission on planetary health: The Lancet, v. 386, p. 1973-2028. https:// doi.org/10.1016/S0140-6736(15)60901-1.

Zalasiewicz, J., 2008, The Earth after us: Oxford University Press, 251 p.

Zalasiewicz, J., Williams, M., Steffen, W. and Crutzen, P., 2010, The new world of the Anthropocene: Environmental Science and Technology, v. 44, p. 2228-2231.

Zalasiewicz, J., Waters, C., Williams, M., Summerhayes, C., and Gibbard, P., 2017,

The geological Anthropocene: born in the Burlington House: Geoscientist, v. 27 , no. 11 , p. $16-19$

Zimmer, C., 2020, Welcome to the virosphere: The New York Times, March 24.

Received May 2020

Accepted as revised June 2020

\section{GEOLOGICAL ASSOCIATION OF CANADA (2020-2021)}

\section{CORPORATE MEMBERS}

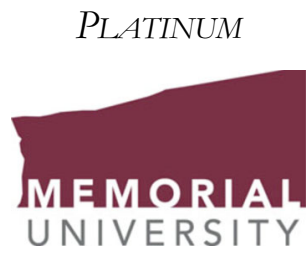

GOLD

\section{(Q) AngloAmerican}

Anglo American Exploration (Canada) Ltd.

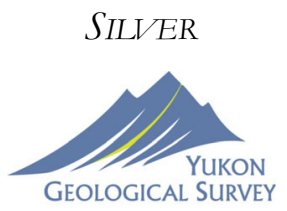

Yukon Geological Survey

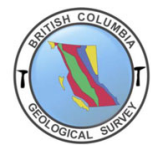

British Columbia Geological Survey

NORTHWEST TERRITORIES GEOLOGICAL SURVEY

Northwest Territories Geological Survey

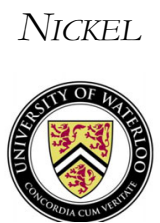

University of Waterloo

GEOSCIENCE CANADA AND THE GEOLOGICAL ASSOCIATION OF CANADA ARE GRATEFUL TO THE CANADLAN GEOLOGICAL FOUNDATION FOR THEIR FINANCIAL SUPPORT OF THIS JOURNAL.

\section{Canadian \\ Geological \\ Foundation}

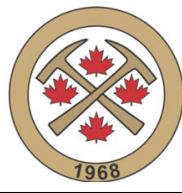

Fondation

Géologique du Canada 